DOI: 10.32844/2222-5374-2020-104-2.34

УДК: 342.9

Савченко С. В.,

здобувач кафедри правового забезпечення господарської діяльності

Харківського національного університету внутрішніх справ

\title{
ДО ХАРАКТЕРИСТИКИ МЕХАНІЗМУ СПЛАТИ ПЛАТЕЖІВ, ЩО ПОВ'ЯЗАНІ $З$ ОТРИМАННЯМ СПАДЩИНИ ТА ДАРУНКІВ
}

Актуальність статті полягає в тому, що визнання приватної власності та її непорушності, відмова від обмежень щодо кількості та вартості майна, яке може належати особі на праві приватної власності змінили саму структура спадщини. До її складу в сучасний період можуть входити засоби виробництва, цілісні майнові комплекси, земельні ділянки та інше нерухоме майно, пакети цінних паперів, частки у статутному капіталі господарських товариств, майнові права інтелектуальноївласності тощо. Враховуючи ускладнення об'єктів спадкового наступництва, гостро постає проблема збереження спадщини у період з дня смерті спадкодавия до її оформлення спадкоємцями. Метою статті є: розкрити зміст механізму сплати платежів, що пов'язані з отриманням спадщини та дарунків. У статті, на основі аналізу наукових поглядів вчених та норм чинного законодавства України, надано характеристику механізму сплати платежів, що пов'язані з отриманням спадщини та дарунків. Обгрунтовано, що основною проблемою сплати податку на дохід, отриманий спадкоємцем (обдарованим), є визначення вартості успадкованого (подарованого майна), що пов'язано як з відсутністю сталого механізму оцінки такого майна, так $і$ зі станом правового формулювання понять деяких видів майна, які можуть переходити у спадок (дарування). Зроблено висновок, що основною проблемою сплати податку на дохід, отриманий спадкоємщем (обдарованим) у результаті прийняття ним у спадщину чи дарунок коштів, майна, майнових чи немайнових прав є визначення вартості успадкованого (подарованого майна), що пов'язано як з відсутністю сталого механізму оцінки такого майна, так і зі станом правового формулювання понять деяких видів майна, які можуть переходити у спадок (дарування). Окрім того, вбачається доцільним використати позитивний історичний досвід щодо зменшення податкової бази при оподаткуванні спадщини та дарунків на суми витрат на поховання спадкодавця та догляду за ним під час передсмертної хвороби, які не враховувати у випадку отримання спадкоємцем соціальної допомоги на поховання згідно Закону України «Про загальнообов'язкове державне соціальне страхування».

Ключові слова: механізм, сплата платежів, отримання спадщини, дарунки, законодавство.

Актуальність теми. Визнання приватної власності та їі непорушності, відмова від обмежень щодо кількості та вартості майна, яке може 
належати особі на праві приватної власності змінили саму структура спадщини. До її складу в сучасний період можуть входити засоби виробництва, цілісні майнові комплекси (в тому числі фермерські господарства), земельні ділянки та інше нерухоме майно, пакети цінних паперів, частки у статутному (складеному) капіталі господарських товариств, майнові права інтелектуальної власності тощо. Враховуючи ускладнення об'єктів спадкового наступництва, гостро постає проблема збереження спадщини у період з дня смерті спадкодавця до її оформлення спадкоємцями [1]. Разом із ти, варто відмітити, що отримання спадщини та подарунків - не такий простий процес, а тому він вимагає забезпечення належного функціонування окремих механізмів, серед яких важливе місце належить сплаті платежів, що пов'язані з отриманням спадщини та дарунків.

Стан дослідження. Велика кількість проблемних питань, пов'язаних із отриманням спадщини та дарунків, у своїх наукових працях розглядали: В.І. Акуленко, С. В. Березовська, В.О. Вишнивецька, Д.А. Кобильник, Є.С. Лесік, 3.В. Ромовська, Ю.О. Швець, Я.Р. Ярема та багато інших. Втім, незважаючи на чималу кількість наукових здобутків, в юридичній літературі малодослідженим $є$ питання механізму сплати платежів, що пов'язані з отриманням спадщини та дарунків.

Саме тому метою статті є: розкрити зміст механізму сплати платежів, що пов'язані з отриманням спадщини та дарунків.

Виклад основного матеріалу. Механізм сплати податку на дохід, отриманий спадкоємцем (обдарованим) у результаті прийняття ним у спадщину чи дарунок коштів, майна, майнових чи немайнових прав визначається статтею 174.3 ПКУ, згідно норм якої дохід у вигляді вартості успадкованого майна (кошти, майно, майнові чи немайнові права) у межах, що підлягає оподаткуванню, зазначається в річній податковій декларації, крім спадкоємців-нерезидентів, які зобов'язані сплатити податок до нотаріального оформлення об'єктів спадщини або в сільських населених пунктах - до оформлення уповноваженою на це посадовою особою відповідного органу місцевого самоврядування за місцем відкриття спадщини, та спадкоємців, які отримали у спадщину об’єкти, що оподатковуються за нульовою ставкою податку на доходи фізичних осіб, а також іншими спадкоємцями - резидентами, які сплатили податок до нотаріального оформлення об'єктів спадщини [2]. Обов'язок платників подавати декларації до контролюючих органів у порядку, встановленому податковим законодавством, закріплений статтею 16.1.3 ПКУ. Водночас, згідно статті 179.2 ПКУ обов'язок платника податку щодо подання податкової декларації вважається виконаним і податкова декларація не подається, якщо такий платник податку отримував доходи: від податкових агентів, які згідно з цим розділом не включаються до загального місячного (річного) оподатковуваного доходу; виключно від податкових агентів незалежно від виду та розміру нарахованого (виплаченого, наданого) доходу, крім випадків, прямо передбачених цим розділом; від операцій продажу (обміну) майна, дарування, дохід від яких відповідно до цього розділу не оподатковується, оподатковується за нульовою ставкою та/або з яких при нотаріальному посвідченні договорів, за якими був сплачений податок відповідно до цього розділу; у вигляді об'єктів спадщини, які відповідно до цього розділу оподатковуються за нульо- 
вою ставкою податку та/або з яких сплачено податок відповідно до пункту 174.3 статті 174 ПКУ [2]

Фізичні особи - платники податку, що одержали дохід у вигляді спадщини (подарунку), який оподатковується за нульовою ставкою, не зобов'язані включати вартість (суму) такої спадщини (подарунку) до складу загального річного оподатковуваного доходу та подавати річну податкову декларацію про майновий стан і доходи до податкового органу за місцем своєї податкової адреси, але за умови відсутності інших підстав для подання декларації. Стаття 174.2 ПКУ визначає перелік осіб, що оподатковуються за нульовою ставкою: а) об'єкти спадщини, що успадковується членами сім'ї спадкодавця першого та другого ступенів споріднення; б) вартість власності, що успадковується особою, яка є особою з інвалідністю I групи або має статус дитини-сироти або дитини, позбавленої батьківського піклування, та вартість власності, зазначеної в підпунктах «а», «б» пункту 174.1, що успадковуються дитиною з інвалідністю; в) грошові заощадження, поміщені до 2 січня 1992 р. в установи Ощадного банку СРСР та державного страхування СРСР, що діяли на території України, а також у державні цінні папери (облігації Державної цільової безпроцентної позики 1990 р., облігації Державної внутрішньої виграшної позики 1982 р., державні казначейські зобов'язання СРСР, сертифікати Ощадного банку СРСР) та грошові заощадження громадян України, поміщені в установи Ощадного банку України та колишнього Укрдержстраху протягом 1992-1994 р., погашення яких не відбулося, що успадковуються будь-яким спадкоємцем [2].

Крім того, відповідно до статті 179.4 ПКУ від обов'язку подання податкової декларації звільняються особи, які $є$ малолітніми/неповнолітніми або недієздатними особами і при цьому перебувають на повному утриманні інших осіб (у тому числі батьків) та/або держави станом на кінець звітного податкового року; перебувають під арештом або є затриманими чи засудженими до позбавлення волі, перебувають у полоні або ув'язненні на території інших держав станом на кінець граничного строку подання декларації; перебувають у розшуку станом на кінець звітного податкового року; перебувають на строковій військовій службі станом на кінець звітного податкового року [2]

Інші особи подають річну декларацію про майновий стан і доходи (податкову декларацію) відповідно до закріпленого главою 2 ПКУ порядку. Податкова декларація складається за відповідною формою (стаття 48.1 ПКУ) фізичною особою - платником податків чи її законним або уповноваженим представником (стаття 47.1.2 ПКУ), опікуном або піклувальником - щодо доходів, отриманих неповнолітньою особою або особою, визнаною судом недієздатною, спадкоємцями (розпорядниками майна, державними виконавцями) - щодо доходів, отриманих протягом звітного податкового року платником податку, який помер (стаття 179.5 ПКУ). У цій декларації платником самостійно (або визначеною особою) визначається сума податкового зобов'язання (стаття 49.7 ПКУ), вона підписується і подається до органу державної податкової служби (особисто або поштою) (стаття 49 ПКУ) до 1 травня року, що настає за звітнім (стаття 49.18.4 ПКУ). Посадова особа органу державної податкової служби реєструє податкову декларацію платника за датою її фактичного отримання органом державної податко- 
вої служби (стаття 49.9 ПКУ). Орган державної податкової служби протягом 30 календарних днів після надходження податкової декларації зобов'язаний перевірити визначене податкове зобов'язання, сплату належної суми податку і видати довідку про таку сплату та про відсутність податкових зобов'язань (стаття 179.2 ПКУ). Фізична особа зобов'язана самостійно, до 1 серпня року, що настає за звітним, сплатити суму податкового зобов'язання, зазначену в поданій нею податковій декларації (стаття 179.7 ПКУ).

Отже, спадкоємець (обдарований) повинен самостійно вказати вартість отриманого майна і розрахувати суму податкового зобов'язання. Підкреслюємо позитивність встановлення у законодавстві як осіб, відповідальних за сплату (перерахування) податку до бюджету, спадкоємців (обдарованих) (стаття 174.3 ПКУ) оскільки податок нараховується з вартості майна, що переходить до кожного конкретного спадкоємця залежно від належної йому долі, а отже, спадкоємець (обдарований) не відповідає за оподаткування спадщини та дарунків інших спадкоємців та одне й те саме майно не оподатковується двічі, але вважаємо, що платники можуть вдаватися до зловживань при нарахуванні податкового зобов'язання для уникнення оподаткування, тим більше, що для контролю законодавцем передбачено лише обов'язок нотаріусів щокварталу подавати до органу державної податкової служби за місцем розташування державної нотаріальної контори або робочого місця приватного нотаріуса інформацію про видачу свідоцтв про право на спадщину та/або посвідчення договорів дарування (стаття 174.4 ПКУ).

Таким чином, однією з проблем контролю за оподаткуванням отримання спадщини та дарунків $є$ те, що лише нотаріуси зобов'язані повідомляти органи державної податкової служби про перехід майна внаслідок спадкування та дарування. Нотаріальні органи отримують інформацію лише у випадку нотаріального посвідчення цих правочинів, яке відбувається у випадках, якщо перехід права власності пов'язаний із необхідністю державної реєстрації майна (нерухомих об'єктів, транспортних засобів), а перехід інших видів майна відбувається безконтрольно. Водночас, обіг окремих видів рухомого майна підпадає під нагляд певних державних органів. Насамперед, це зброя, контроль за переходом якої здійснюють органи внутрішніх справ. Відповідно до Інструкції про порядок виготовлення, придбання, зберігання, обліку, перевезення та використання вогнепальної, пневматичної і холодної зброї, пристроїв вітчизняного виробництва для відстрілу патронів, споряджених гумовими чи аналогічними за своїми властивостями метальними снарядами несмертельної дії, та зазначених патронів, а також боєприпасів до зброї та вибухових матеріалів, затвердженої Наказом Міністерства внутрішніх справ України № 622 від 21 серпня 1998 р. [3], для успадкування зброї родичі померлого повинні в десятиденний строк здати мисливську нарізну та гладкоствольну зброю на тимчасове зберігання до органів внутрішніх справ, до моменту, поки не буде вирішено питання про спадкування майна. Після вирішення питання про спадщину зброя повинна бути зареєстрована на одного із спадкоємців, продана або подарована спадкоємцями у місячний термін особі, яка має право на зброю. Отже, перехід права власності на зброю для мети оподаткування спадщини (дарунків) можуть допомогти контролювати органи 
внутрішніх справ, для чого пропонуємо у нормах ПКУ, що врегульовують оподаткування спадщини та дарунків, закріпити окремою статтею обов'язок органів внутрішніх справ подавати інформацію до органів податкової служби про факти спадкування чи дарування, що стали їм відомі у зв’язку з реєстрацією зброї [4, с. 277].

Повертаючись до механізму сплати податку на дохід, отриманий спадкоємцем (обдарованим) у результаті прийняття ним у спадщину чи дарунок коштів, майна, майнових чи немайнових прав, зазначимо, що навіть якщо припустити, що усі без винятку спадкоємці (обдаровані) $\epsilon$ добросовісними платниками, все одно при заповненні ними декларації неминучі помилки, пов'язані, насамперед, із визначенням вартості успадкованого майна. Професійна оцінка надається об'єктам нерухомості, земельним ділянкам, транспортним засобам, бо без її здійснення неможливе нотаріальне оформлення переходу права власності. Проте питання щодо оцінки інших видів майна залишається без відповіді. Теоретично, спадкоємці (обдаровані) можуть звернутися до послуг професійних оцінщиків, відповідно до Закону України «Про оцінку майна, майнових прав та професійну оціночну діяльність в Україні», проте не можна забувати, що кожен із таких оцінщиків спеціалізується за певним напрямком, а отже вартість послуг за їх послуги може перевищити вартість успадкованого (подарованого) майна.

До того ж слід вказати, що частина 1 статті 10 Закону України «Про оцінку майна, майнових прав та професійну оціночну діяльність в Україні» передбачає, що оцінка майна проводиться на підставі договору між суб’єктом оціночної діяльності - суб'єктом господарювання та замовником оцінки або на підставі ухвали суду про призначення відповідної експертизи щодо оцінки майна. Тобто законодавство України не містить імперативної норми, яка б зобов'язувала спадкоємців (обдарованих) замовляти оцінку успадкованого (подарованого) майна. Крім того, є певні види майна, здійснення вартісної оцінки яких в умовах сучасного законодавства $€$ проблематичним, як, наприклад, об'єкт бізнесу (тобто власність на цілісний майновий комплекс). Поняття, застосоване законодавцем у пункті «в» статті 174.1 ПКУ не має аналогів у цивільному чи господарському праві, тому залишається лише гадати, що саме має на увазі законодавець. На нашу думку, під цим поняттям необхідно розуміти підприємство як єдиний майновий комплекс.

У правовому регулюванні відносин спадкування та дарування виникла ситуація: якщо у спадок (дарунок) переходить підприємство, то спадкоємці (обдаровані) для отримання права власності на нього повинні оцінити кожен об’єкт, який входить у підприємство і окремо також є об’єктом нерухомості (земельні ділянки, будівлі, споруди тощо) та отримати на кожен із них витяг із Реєстру прав власності на нерухоме майно, а потім оформити спадкування (дарування) нотаріально. Інше ж майно підприємства, у тому числі і нематеріальні активи, переходять до них при внесенні відповідних змін до статутних документів, а отже під оподаткування не підпадають.

Міністерство юстиції України у своєму листі № 31-32-1736 від 12 серпня 2008 р.[5] зазначає, що механізм вчинення правочинів щодо під- 
приємства (у тому числі спадкування та дарування) чинним законодавством не передбачений, оскільки до складу підприємства можуть входити різні об'єкти (будівлі, сировина, борги), стосовно яких чинне законодавство містить низку спеціальних норм, які, враховуючи юридичну природу цих об'єктів, визначають особливості регулювання відносин, пов'язаних 3 такими об'єктами, і пропонує видавати свідоцтво про право на спадщину на майно, внесене до статутного фонду підприємства. Проте такий підхід не розв'язує питання, бо вартість статутного фонду підприємства зазвичай набагато менша, ніж його ринкова вартість.

Подібна ситуація склалася і при визначенні вартості корпоративних прав. Згідно листа Державної податкової адміністрації України від 8 червня 2006 року № 3269/Н/17-0715 «Про розгляд листа» [6], об'єктом оподаткування у спадкоємця, який одержав у спадщину корпоративні права (частку у статутному фонді товариства), є вартість такої частки, визначена товариством на день смерті спадкодавця (засновника, учасника). Як вірно зазначає В. Мосейчук [7, с. 211], це дає легальний шлях зменшення оподаткування при успадкуванні об'єктів комерційної власності, вартість яких із моменту внесення в статутні фонди спадкодавцем і до моменту смерті суттєво зростає. До того ж, навіть при оцінці нерухомості, що здійснюється БТІ та Держкомземом, є певні проблеми, оскільки не рідко ринкова ціна об'єкта нерухомості значно більша, ніж оцінка, надана зазначеними установами. Таким чином, система оцінки успадкованого (подарованого) майна, яка склалася на сьогодні в Україні, є недосконалою, на чому неодноразово наголошували у своїх роботах науковці та практики [8, с. 13].

У зарубіжних країнах оцінка успадкованого майна здійснюється по-різному. В США та Німеччині до їі проведення залучаються оцінщики-експерти (assessor's) [9, с. 36]. М.М. Антоновим [10, с. 56] висувається ідея щодо створення інституту спеціального незалежного арбітра, оцінка яким успадкованого (подарованого) майна вважалася б обов'язковою, і нам імпонує ця пропозиція. Проте він пропонує функції такого арбітра покласти на спеціальні федеральні органи, що на наш погляд $є$ не зовсім правильно. На нашу думку, незалежний арбітр, що надаватиме послуги з оцінки майна, яке $є$ предметом спадкування чи дарування, повинен здійснювати господарську діяльність, що підлягатиме ліцензуванню [11, с. 203].

Висновки. У підсумку представленого наукового дослідження можемо констатувати, що основною проблемою сплати податку на дохід, отриманий спадкоємцем (обдарованим) у результаті прийняття ним у спадщину чи дарунок коштів, майна, майнових чи немайнових прав $\epsilon$ визначення вартості успадкованого (подарованого майна), що пов'язано як з відсутністю сталого механізму оцінки такого майна, так і зі станом правового формулювання понять деяких видів майна, які можуть переходити у спадок (дарування).

Окрім того, вбачається доцільним використати позитивний історичний досвід щодо зменшення податкової бази при оподаткуванні спадщини та дарунків на суми витрат на поховання спадкодавця та догляду за ним під час передсмертної хвороби, які не враховувати у випадку отримання спадкоємцем соціальної допомоги на поховання згідно Закону України «Про загальнообов'язкове державне соціальне страхування». 


\section{СПИСОК ВИКОРИСТАНИХ ДЖЕРЕЛ}

1. Кухарєв 0. Є. Управління спадщиною: стан та перспективи розвитку. Актуальні проблеми вдосконалення чинного законодавства України. 2018. Вип. 46. С. 83-93.

2. Податковий кодекс України : закон України : від 2 грудня 2010 р. № 2755-VI // Відомості Верховної Ради України. 2011. № 13-14, № 15-16, № 17. Ст. 112.

3. Інструкція про порядок виготовлення, придбання, зберігання, обліку, перевезення та використання вогнепальної, пневматичної і холодної зброї, пристроїв вітчизняного виробництва для відстрілу патронів, споряджених гумовими чи анаголічними за своїми властивостями метальними снарядами несмертельної дії, та зазначених патронів, а також боєприпасів до зброї та вибухових матеріалів : наказ Міністерства внутрішніх справ України : від 21 серпня 1998 року № 622 // URL: http://zakon.nau.ua/ doc $/$ ?code $=$ z0637-98

4. Савченко С.В. До питання контролю за сплатою податку на доходи, що отримані в результаті прийняття у спадщину чи дарунок коштів, майна, майнових чи немайнових прав. Молодий будівничий Украӥни № 32 : y 2-х томах: тези доповідей XVII міжнародної молодіжної науково-практичної конференції «Європейський шлях розвитку України: плани і реалії» 7 8 квітня 2012 року / Київ : Київський міжнародний університет, 2012. Т. 1 С. 276-277.

5. Щодо порядку укладання правочинів з підприємствами та спадкування підприємств як цілісний майнових комплексів : лист Міністерства юстиції України : від 12 серпня 2008 р. № 31-32-1736 // URL: http://zakon. nau.ua/doc/?uid=1154.864.0

6. Про розгляд листа : лист Державної податкової адміністрації України : від 8 червня 2006 року № 3269/H/17-0715. URL: http://zakon.nau.ua/ doc/?uid=1008.7769.0

7. Гриньков Д. Заставне свідчення. URL: http://finance.ua/

8. Пылаева A.В. Совершенствование системы налогообложения в условиях развития кадастровой оценки недвижимости : автореф. дис. на соиск. наук. степени канд. эконом. Наук : спец. 08.00.10 «Финансы, денежное обращение и кредит». Новгород, 2010. 22 с.

9. Рябова С. Оценка обектов недвижимости: опыт США и Германии. Банкаўскі веснік. 2007. № 14 С. 35-38

10. Антонов Н.Н. Правовой режим налога с имущества, переходящего в порядке наследования или дарения : дис. ... канд.. юрид. наук : 12.00.14. М., 2003. 244 c.

11. Савченко С.В. Проблеми оцінки майна при визначенні податку на доходи, отримані в результаті прийняття у спадщину чи дарунок коштів, майна, майнових чи немайнових прав. Європейські перспективи. 2012. № 2. Ч. 1. С. 200-204. 


\section{S. Savchenko}

\section{TO CHARACTERIZE THE MECHANISM OF PAYMENT OF PAYMENTS RELATED TO THE RECEIPT OF INHERITANCE AND GIFTS}

The relevance of the article is that the recognition of private property and its inviolability, the waiver of restrictions on the number and value of property that may belong to a person on the right of private property have changed the very structure of the inheritance. Its composition in the modern period may include means of production, integral property complexes, land and other real estate, securities packages, shares in the authorized capital of companies, intellectual property rights and more. Given the complexity of the objects of hereditary inheritance, the problem of preserving the inheritance in the period from the date of death of the testator to its registration by the heirs is acute. The purpose of the article is: to reveal the content of the mechanism of payment of payments related to the receipt of inheritance and gifts. The article, based on the analysis of scientific views of scientists and the current legislation of Ukraine, provides a description of the mechanism of payment of payments related to the receipt of inheritance and gifts. It is substantiated that the main problem of paying income tax received by the heir (gifted) is to determine the value of inherited (donated property), which is due to the lack of a stable mechanism for valuing such property and the state of legal formulation of certain types of property. can be inherited (gift). It is concluded that the main problem of paying income tax received by the heir (gifted) as a result of his inheritance or gift of funds, property, property or non-property rights is to determine the value of inherited (donated property), which is due to lack of sustainable mechanism valuation of such property, and with the state of the legal formulation of the concepts of certain types of property that may be inherited (gift). In addition, it is advisable to use the positive historical experience of reducing the tax base in the taxation of inheritance and gifts on the amount of expenses for burial of the testator and his care during death, which are not taken into account if the heir receives social assistance for burial under the Law of Ukraine "State social insurance".

Keywords: mechanism, payment of payments, inheritance, gifts, legislation. 